\title{
Impact of Ownership Structure and Bank Performance - An Empirical Test in Vietnamese Banks
}

\author{
Nguyen Hong Son ${ }^{1}$, Tran Thi Thanh Tu${ }^{1}$, Dinh Xuan Cuong ${ }^{1}$, Lai Anh $\operatorname{Ngoc}^{2} \&$ Pham Bao Khanh ${ }^{3}$ \\ ${ }^{1}$ University of Economics and Business, Vietnam National University, Hanoi, Vietnam \\ ${ }^{2}$ Paris 1 University, Panthéon Sorbonne, France \\ ${ }^{3}$ PHD student, National Economics University, Vietnam \\ Correspondence: Assoc. Prof. Tran Thi Thanh Tu, PHD., University of Economics and Business, Vietnam National \\ University, Hanoi, Vietnam
}

Received: July 28, 2015

Accepted: August 24, $2015 \quad$ Online Published: September 4, 2015

doi:10.5430/ijfr.v6n4p123

URL: http://dx.doi.org/10.5430/ijfr.v6n4p123

\begin{abstract}
By using the data collected from the whole 44 banks in the banking system in Vietnam from 2010-2012, the authors try to investigate the impacts of ownership structure on bank performance in Vietnamese banking system. Research results show that capital concentration and private ownership have positive impact on bank profitablity, the nonperforming loan ratio has negative relation with banks' profitability. Besides, the research results are also consistent with the previous researches (Nguyen, Tran \& Pham, 2014) on the positive correlation of corporate governance and bank performance in Vietnam. The findings in this paper are also relevant with the previous researches in Kenya, China, Malaysia (Wen, 2010, Rokwaro, 2013). From these findings, some policy implications are also suggested as follow: (i) encourage the large shareholders participation the Board of Director to reduce the interest conflict in banks, (ii) enhance private ownership to increase bank profitability, (iii) improve the corporate governance of banks under international standards, and (iv) push-up the solving of non-performing loans in the bank restructuring in Vietnam.
\end{abstract}

Keywords: ownership structure, bank restructuring, corporate governance, non-performing loan

\section{Introduction}

In 2012, the program of restructuring credit institutions system for the period 2011-2015 was promulgated by decision No. 245 of the Vietnamese Prime Minister, in which, the focus is on restructuring the banking system. This program has given the overall objectives until 2020 and the specific objectives until the end of 2015, clearly define the views, orientation, solutions and roadmap to implement restructuring credit organizations in Vietnam in the period 2011-2015. Particularly, the program divides banks into two target groups: State commercial banks and joint-stock commercial banks. The joint-stock commercial banks are divided into three groups: group of healthy banks, the banking group temporary liquidity shortage and weak bank group. On that basis, the program has also brought out the orientation and resolution of different restructurings for each bank group.

In the restructuring scheme, eight main objectives were set out, including: (i) assessment of the status of operational quality, bad debt situation; (ii) classify and evaluate credit institutions; (iii) implementing the restructuring plan for weak credit institutions and other institutions; (iv) ensuring liquidity; (v) privatize state commercial banks; (vi) sell and merge credit institutions; (vii) increase legal capital and dispose bad debt; (viii) operational restructuring and the administrator system.

Basically, the goals and the agenda set out in the restructuring scheme were made. Till now, the main success of the process of restructuring the banking system most prominently seen is ensuring the liquidity of the system, create stability in the industry, and from then on, create conditions for macroeconomic stability. This represents the effort and determination of the Vietnamese State Bank in regulating currency markets and banks. The second bright spot in the restructuring process is the control of weak banks. Eight of the nine banks in an exclusive supervisor have done restructuring by way of merger or re-structuring. The third bright spot is the establishment of the company buying and selling debt and legal corridor for the disposal of bad debt, that create the basis for accelerating the speed of handling of bad debt in the later phase of restructuring. In the context of complex movements of macro economy and 
severely affected by the global economic downturn, the results achieved by the process of restructuring are very remarkable.

However, the three last important targets (vi), (vii), and (viii) are only done at the level of form. Banks after merger is not yet manifest in recovery, the rate of treated bad debt is still low, and essentially under technical nature rather than solving radically, governance and bank transparency has not yet improved clearly. In summary, as the World Bank, progress is still slow compared to the roadmap in place. This would risk affecting the goals set out at a later stage and the quality improvement of the banks after restructuring.

In that context, for promoting the process of restructuring the system of commercial banks in Vietnam towards improving the efficiency of the bank operations, we investigate the impact of ownership structure on the profitability of commercial banks of Vietnam in the context of restructuring.

The article consists of 5 parts: after the introduction, part 2 overviews the researches relevant to the topic research, part 3 introduces the research methodology, research models and methods of data collection, part 4 presents the results of regressing model, discusses and analyzes the results and the final part-part 5 lays out a number of conclusions and recommendations.

\section{Literature Review}

This literature review explores the following theme of the research questions: The impact of corporate governance, especially the ownership structure on bank profitability. After a brief definition of corporate governance (CG), the authors review to recent researches in developing the impact of corporate governance, including ownership structure, board of director and disclosure, on bank profitability.

\subsection{Definition of Corporate Governance}

There are many definitions of corporate governance. OECD (2004) states that "Corporate governance is a system by which companies are directed and controlled". Corporate governance was defined by La Porta et al. (2000) as a set of mechanisms and measures in which outside investors protect themselves against conflict problems arising from the managers and shareholders. According to Pei Sai Fan (2004), "corporate governance is basically about putting in place the structure, processes and mechanisms by which business and affairs of the company are directed and managed in order to enhance the long term shareholder value through accountability of managers".

At basic level, corporate governance problems arise when shareholders wish to control their companies in a different way to the managers. These problems are further complicated by conflicts among different shareholders due to the diversity in ownership. To solve these conflicts, proper corporate governance frameworks are put in place. Five mechanisms in corporate governance are used to manage the conflicts: (i) hostile takeover, (ii) partial concentration ownership and control in large shareholders or a group of shareholders, (iii) delegation of partial control to large creditors (e.g. financial intermediaries), (iv) Control of CEO by board of directors, (v) alignment manager's interests with shareholder through remuneration policy. Among these mechanisms, the role of board of directors in controlling CEOs is used popularly. Most corporate charters require that shareholders elect a board of directors, which monitors the $\mathrm{CEO}$ on their behalf.

\subsection{Role of Ownership Structure, Board of Director and Disclosure in CG}

Ownership structure is one of the main dimensions and measures of corporate governance and is widely seen to be determined by other country-level corporate governance characteristics such as the development of the stock market and the nature of state intervention and regulation (La Porta, 1998). It may make big effects on business incentives, mergers and acquisitions, competition and oversight of agency.The concept of ownership structure can be defined along two dimensions: ownership concentration and ownership mix. The former refers to the share of the largest owner and is influenced by absolute risk and monitoring costs, while the latter is related to the identity of the major shareholder such as ownership concentration, foreign ownership, domestic ownership, etc, (Rokwaro, 2013; Wen, 2013; Anstoniadis, 2010; Peong, 2012).

There exists a substantial literature on whether and how ownership structure affects corporate performance. This later relationship has been the subject of an important and ongoing debate in the corporate finance literature (Demsetz \& Villalonga, 2001; Bathala \& Rao, 1995; Mitton, 2002; Ng, 2005; Vethanayagam et al., 2006; Kiruri, 2013; among others). According to Claessens and Djankov (1998), the overall concentration of ownership as well as particular types of investors, (ownership concentration and ownership mix) are responsible for the changes in profitability and labor productivity. The research of Sun and Tong (2003) showed that state ownership having 
negative impacts on firm performance in China; while foreign ownership does not show uniformly strong, positive impacts on firm performance.

Uwalomwa and Olamide (2012) have studied the relationship between ownership structure with the performance of the 31 companies operating in Nigeria's financial sector in the period 2006-2010. By using regression models with dependent variable is the rate of return on total assets, the independent variables are the rate of ownership of shareholders (members of Board of Directors), the rate of ownership of foreign shareholders and shareholder's ownership, this research has shown that (1) the company has shareholders as members of the Board of Directors will work better; (2) the foreign shareholders would also bring positive results in the company's operations, due to the company management more efficient, and to the skills and new techniques.

Except the common evidence showed in developed countries like the U.S. and UK, etc., little evidence was found in transition nations like Central and Eastern Europe or in developing countries (Gedajlovic and Shapiro, 1998). One reason might be the fact that many developing economies are characterized by considerable family ownership of listed corporations (Claessens et al. 2000). And also, emerging markets have different characteristics such as different political, economic and institutional conditions, which limit the application of developed markets' empirical models.

In developing countries, Micco et al. (2004) identified a strong relationship between ownership structure and performance. They found that the state-owned banks tend to have lower profitability than their private counterparts, and foreign-owned banks tend to be characterized by higher profitability. Kiruri (2013) studies the effects of ownership structure on bank profitability in Kenya. The result showed that the ownership concentration is negatively correlated with bank profitability. The foreign ownership and the domestic ownership are also positive correlated with bank profitability. Opposite, state ownership is negatively correlated with bank profitability. In the Greek banking sector, Antoniadis et al. (2010) observed the high level of ownership concentration and diffused ownership in examined banks leads to an increase in bank profitability. Kobeissi and Sun (2010) also find a high impact of ownership structure on the bank performance. Especially, in their study, private banks, particularly foreign owned ones, have higher performance indicators than other banks in the sample. Meanwhile, the government owned banks take the last place in the ranking and performed the worst. Finally, they concluded that banks that are listed in stock exchange markets and have foreign majority ownership have a great significant effect on performance within the MENA region.

In Pakistani Equity market, Hasan and Butt (2009) explored the impact of ownership structure and corporate governance on capital structure of Pakistani listed companies. They suggested that corporate governance factors such as ownership structure, size of the board of directors and managerial shareholding are important in determining the capital structure of the firms.

The above findings are quite different from the results showed by Wen (2010), who investigated the same relationship for China. Using Return on Assets (ROA) and Return on Equity (ROE) as profitability measures, he find no obvious correlation between ownership structure and bank performance in general, although state-owned commercial banks (SOCBs) might present a quadratic relationship with ROE. In the same vein, Kosak and Cok (2008) examined the relationship between bank ownership and bank profitability in six South-Eastern European countries (SEE-6). They categorized the bank ownership as domestic and foreign owned banks, and analyzed the profitability during the 1995-2004 periods. In their analysis, they found very little difference between the performance indicators of foreign-owned banks and domestic banks.

An important and recent study on the role of ownership structure in defining firm performance is conducted by Fazlzadeh et al (2011) in Iranian Stock Market. They examined the role of ownership structure. They have found a mix of results. At one side institutional ownership concentration showed a negative effect on firm performance and on the other side institutional ownership shown a significant negative impact on firm performance.

For the Vietnamese commercial banks, the study of Tran, Nguyen and Pham (2014) have shown positive relationships between CGI- corporate governance index- and the performance of the commercial banks. The performance used by the authors is measured by either the rate of return on assets (ROA) or the rate of return on equity (ROE).

As such, most of the current studies that investigate the impact of the structure of ownership (corporate governance) on the performance of the commercial banks (measured by ROA or ROE) showed an existent relationship between these factors. Although this relationship may be pronounced or not yet crisp in different economies, but these empirical studies can be applied to compare with the relationship between ownership structure and efficient activity 
of Vietnamese commercial banks, especially during the period of restructuring. In Vietnam, to the best of our knowledge, there have been no studies who clarify the role of ownership structure in bank performance, yet. Therefore, this relationship is one of our objectives in this study.

\section{Models of Evaluating the Impact of Ownership Structure on Profitability of the Vietnamese Commercial Banks}

\subsection{Models}

Based on the literature review, we propose models that evaluate the impact of ownership structure on profitability of commercial banks in Vietnam as follows:

$$
Y=a+b_{1} X_{1}+b_{2} X_{2}+b_{3} X_{3}+b_{4} X_{4}+b_{5} X_{5}+b_{6} X_{6}+N P L s+\epsilon
$$

where:

Dependent variables $\mathbf{Y}$ - Results of operations of commercial banks are measured either by the return on equity (ROE), or by the return on assets (ROA) of 40 commercial banks during the period 2010-2012.

\section{Independent variables:}

$\mathrm{X}_{1}$ - Ownership Concentration which is the sum of the holdings of the largest five block holder shareholders,

$\mathrm{X}_{2}$ - Foreign Ownership which is the total value of the shares held by foreign owners,

$\mathrm{X}_{3}$ - Domestic Ownership which is the total value of the shares held by the citizens of the country,

$\mathrm{X}_{4}$ - State ownership which is the total value of the shares held by the Government,

$\mathrm{X}_{5}$ - Private ownership which is the total value of the shares held by Non-governmental legal entity,

$\mathrm{X}_{6}$ - Corporate Governance Index - Measurement of the management capacity of a bank,

NPLs - Non Performing Loans.

\section{Other variables}

a - A constant,

$\boldsymbol{\epsilon}-$ Error term.

The above models will be specified to test the following hypotheses:

Hypothesis 1: Can ownership structure - foreign ownership, domestic ownership, state ownership, private ownership affect the profitability of the commercial banks?

Hypothesis 2: Can the level of ownership concentration affect the profitability of the commercial banks?

Hypothesis 3: Can bad debt (NPLs) affect the profitability of the commercial banks?

Hypothesis 4: Can corporate governance in commercial banks affect the profitability of the commercial banks?

\subsection{Description of the Data}

In this paper, to ensure the adequacy and accuracy, the data were obtained based on the incorporation of many reports published through various information channels. The data on ownership structure and financial data were collected from financial statements, annual reports, and published resources for the Bank's shareholders before or after each session of the meeting of shareholders on the regular or irregular of 40 banks in the three years from 2010 to 2012. In the case that these reports do not provide sufficient information, we use administrative report, prospectus or from the State Securities Commission (SSC), the stock exchange, several large securities company or other official information website about the stock.

Some limitations in the process of collecting and calculating data are information that is not usually updated, or is lately updated or lacks in a few years. However, if possible, we used the tools data processing like interpolation or extrapolation to ensure the consistency of the data array. In the period from 2010 to 2012, we study the 40 commercial banks (120 observations) but due to incomplete data, we only use the data of 34 banks, corresponding to the available observations of 102 . 
Table 1. Descriptive statistics

\begin{tabular}{llllllllll}
\hline & Mean & Median & Maximum & Minimum & Std. Dev & Skewness & Kurtosis & Jarque-Bera & Obs \\
\hline ROA & 1.128 & 1.075 & 4.950 & 0.000 & 0.785 & 2.125 & 10.466 & 313.712 & 102 \\
ROE & 11.730 & 9.701 & 57.629 & 0.000 & 8.943 & 1.922 & 9.058 & 218.739 & 102 \\
CGI & 46.108 & 47.00 & 69.00 & 14.00 & 12.478 & -0.739 & 3.579 & 10.700 & 102 \\
X $_{1}$ (OC) & 0.389 & 0.354 & 0.979 & 0.000 & 0.249 & 0.481 & 2.719 & 4.270 & 102 \\
X $_{2}$ (FO) & 0.073 & 0.000 & 0.920 & 0.000 & 0.128 & 3.308 & 19.868 & 1395.294 & 102 \\
X $_{3}$ (DO) & 0.441 & 0.242 & 1.000 & 0.000 & 0.447 & 0.169 & 1.161 & 14.853 & 102 \\
X $_{4}$ (SO) & 0.137 & 0.018 & 0.958 & 0.000 & 0.235 & 2.233 & 7.066 & 155.067 & 102 \\
$\mathrm{X}_{5}$ (PO) & 0.243 & 0.183 & 0.975 & 0.000 & 0.267 & 0.886 & 2.633 & 13.929 & 102 \\
NPLs & 0.025 & 0.022 & 0.122 & 0.000 & 0.018 & 2.540 & 11.390 & 408.826 & 102 \\
\hline
\end{tabular}

Table 1 contains some descriptive statistics for different variables in this paper. The dependent variables reflecting banking efficiency like ROE or ROA are concentrated on left of the mean $(1,128 \%$ and $11,73 \%$, respectively), with extreme values to the right and sharper than a normal distribution, with values concentrated around the mean and thicker tails. This means high probability for extreme values.

The skewness of the explanatory variables are all superior to zero (except for CGI, -0.739). These variables are right skewed (CGI is left skewed). The kurtosis of $\mathrm{X}_{1}, \mathrm{X}_{3}, \mathrm{X}_{5}$ lie below 3 so that these variables are flatter than a normal distribution with a wider peak. The probability for extreme values is less than for a normal distribution, and the values are wider spread around the mean. The variables CGI, $\mathrm{X}_{2}, \mathrm{X}_{4}$, and NPLs have kurtosis lying above 3 , so have the same characteristics of ROE or ROA. Thus, as expected, the dependent variables deviate from a normal distribution except for $\mathrm{X}_{1}$.

Overall, the average value of ROA of the Vietnamese commercial banks during the period 2010-2012 is quite low, only $1.12 \%$. As ROA, the CGI is averaging 46 points below the average (50 points in the total of 100 pointsĐ (See Nguyen, Tran and Pham, 2013; Pham and Tran, 2013). This shows that effective use of assets and management quality in the Bank did poorly. However, the average value of ROE is rather high (11.7\%) in comparison to ROA and CGI. This high rate can be explained by the limited chartered of capital of commercial banks as 3000 trillions VND, equivalent to 15 millions USD only. Concerning ownership structure, the average rate of the 5 largest shareholders is $39 \%$, this is quite high in the field of currency trading that requires a lot of capital. With the average of $44 \%$ compared to equity, domestic ownership plays an important role. State ownership (the average of $13.7 \%$ ) showed the contribution of the private sector is quite large in the banking industry.

\subsection{Model Results}

In the models given below, we first check the multi-co linearity between variables and handle it if this problem exists. We then set the coefficients that have regression value statistically no significant to zero. This will be done as follow, the coefficients with standard errors superiors in absolute value to regression coefficient values are considered statistically no significant and will be eliminated. We next choose model by using the test to compare the restricted model - model with regression coefficients set to zero with the unrestricted one. The last chosen model will be studied and analyzed.

The comparison test models will be done as follows:

The null hypothesis $\mathrm{H}_{0}$ is of the form : $\mathrm{b}_{0}=\mathrm{b}_{1}=\ldots=\mathrm{b}_{\mathrm{k}}=0$, then the test statistic is writing in the following way:

$$
\mathrm{F}_{0}=\frac{\left(\mathrm{SSR}_{\mathrm{r}}-\mathrm{SSR}_{\mathrm{ur}}\right) / \mathrm{q}}{\mathrm{SSR}_{\mathrm{ur}} /(\mathrm{n}-(\mathrm{k}+1)},
$$

Where: $\mathrm{n}$ - number of observations, $\mathrm{q}$ - number of restrictions, $\mathrm{k}$ - number of independent variables in the unrestricted model,

$\mathrm{SSR}_{\mathrm{r}}$ - the sum of the square residuals of the restricted model, $\mathrm{SSR}_{\mathrm{ur}}-$ the sum of the square residuals of the unrestricted model. 
Under the null hypothesis, $\mathrm{F}_{0}$ follows $\mathrm{F}(\mathrm{q}, \mathrm{n}-(\mathrm{k}+1))$. If $\mathrm{F}_{0}$ is superior to the critical value determined by $\mathrm{F}(\mathrm{q}, \mathrm{n}-(\mathrm{k}+1))$, $\mathrm{H}_{0}$ is rejected with a certain significance level, often 0.05 . Opposite, if $\mathrm{F}_{0}$ is inferior to the critical value, we can accept the null hypothesis.

\section{Analysis and Discussions}

From the results of the model studying the effects of ownership structure on profitability of commercial banks in Vietnam within the restructuring context, some key findings have been recognized by the researchers as follows: Return on Asset (ROA) of banks is strongly affected by ownership concentration and they move in the same direction. This can be explained by the fact that all five biggest shareholders of banks participated in the Board of Directors, as a result, according the theory of agency, the interest conflict between owners and managers may not exist. Thus, the boards of directors have great influence on business decisions of banks, ensuring the goal of maximizing profit. In commercial banks in Vietnam, encouraging shareholders whether private or state ones, to join the Board of Directors will increase Return on Asset (ROA). This is entirely consistent with the results of previous studies of Rokwaro (2013) and Wen (2010) when analyzing the impacts of ownership structure on profitability of banks in Kenya and China. Similar to ROA, Return on Equity (ROE) of Vietnamese commercial banks is also strongly affected by the ownership concentration. Especially, the regression model using three independent variables including percentage of private ownership, NPL and corporate governance of banks is able to explain $70 \%$ of ROE change. This suggests that in the current context of restructuring commercial banks of Vietnam, corporate governance capacity including the role of the Board of Directors, the role of shareholders and transparency (Nguyen, Tran \& Pham, 2014) may positively affect the ROE of Vietnamese commercial banks.

In both models measuring dependent variables ROA and ROE, NPL has statistical implication as well as negative effect on profitability of banks. It can be seen that, in the period of restructuring, tackling bad debts plays an important part in improving the profitability of commercial banks in Vietnam.

The percentage of private ownership in both models measuring dependent variables ROA and ROE presents a positive relationship with profitability. This result shows that the increase in privatization through privatization of Vietnamese commercial banks would facilitate the profitability of banks. When privatization is encouraged, transparency and disclosure of information would be more tightly controlled and monitored as more shareholders are engaged in, and therefore, will pressure banks to operate in a healthier manner and more effectively.

\section{Conclusions and Policy Recommendations}

The process of restructuring of commercial banks in Vietnam has made some remarkable initial achievements such as improved liquidity and reduced bad debt, however, many factors affecting the sustainability and profitability of banks in long term remain unresolved. The findings of this study show that corporate governance at banks, ownership concentration and percentage of private ownership are the key factors having positive effect on the performance of Vietnamese commercial banks. Meanwhile, NPL ratio has opposite impact on the profitability of banks. Thus, at present, the process of restructuring commercial banks in Vietnam mostly focuses on mitigating negative effects and does not really pay attention to promoting positive factors.

From these findings, the researchers propose some policy recommendations to enhance efficiency of the current process of restructuring the banking system in Vietnam:

Firstly, the percentage of private equity in banks should be increased, even in privatize state owned commercial banks. Currently, in banks such as BIDV, VCB and Vietinbank, despite the privatization, private shareholders account for a very small portion $-10 \%$. Therefore, encouraging private shareholdings in these banks would promote their profitability.

Secondly, it is necessary to focus on improving corporate governance capacity of commercial banks in Vietnam. Results of this study are entirely consistent with previous findings of Nguyen, Tran \& Pham (2014) when stating that CGI index - corporate governance is positively correlated with the profitability of commercial banks in Vietnam. The improvement of CGI index in commercial banks towards international standards will help Vietnam's commercial banks gradually approach international practices and regulations on transparency and publicizing information, strengthening the independent role of the board of control, separating management from ownership. Therefore, improving corporate governance in banks, in the long term, will help them develop in a healthy and profitable manner.

Thirdly, although NPL ratio has not been accurately and fully calculated, this study still confirms the role of bad debt treatment in creating a healthy operating environment for the banking system in Vietnam during this restructuring period. Apparently, growing NPL ratio negatively affects the profitability of banks through increasing expenses for 
provision and write-offs. The problem for the banking system now is to determine not only the exact NPL ratio but also how to resolve bad debts. Hence, state agencies should study the full, comprehensive and diversified experiences for bad debt settlement during restructuring process of other countries in the region (Nguyen Hong Son, 2013) to enhance the efficiency in resolving bad debts in Vietnam in the restructuring phase.

In conclusion, this paper examines the impacts of ownership structure on the profitability of commercial banks in Vietnam in the context of restructuring. The findings show that ownership concentration and ratio of private shareholders are positively correlated with profitability. Meanwhile, NPL ratio negatively affects banks' profitability. In addition, the study results are also consistent with previous studies (Nguyen, Tran \& Pham, 2014) on the positive impact of corporate governance on the performance of commercial banks. From the above findings, several policy recommendations have been proposed, including: (i) encourage large shareholders' participation in the Board of Directors to reduce interest conflict in banks; (ii) encourage private ownership in banks to increase profitability; (iii) Improve corporate governance at banks towards international rules and (iv) promote bad debt treatment in the process of restructuring banking system in Vietnam.

\subsection{Limitations and Further Study}

Even though the authors have tried to collect data as fully and accurately as possible, one of the limitations of this study lies in the fact that conclusions and analysis are made based on collected data that, in some aspects, is not really comprehensive. Additionally, in the model assessing the impacts of ownership structure on profitability, several significant variables were not included such as cross-ownership ratio between banks and corporations as well as cross-ownership between banks, which somewhat limits the results of this study. However, conclusions and recommendations have been given on a scientific basis, which is good reference for further researches and the process of restructuring banking system in Vietnam.

\section{References}

Antoniadis, I., Lazarides, T., \& Sarrianides, N. (2010). Ownership and performance in the Greek banking sector. International Conference on Applied Economics, 11-21.

Bathala, C. T., \& Rao, R. P. (1995). The Determinants of Board Composition: An Agency Theory Perspective. Managerial and Decision Economics, 16, 59-69. http://dx.doi.org/10.1002/mde.4090160108

Claessens, S., \& Djankov, S. (1998). Ownership concentration and corporate performance in the Czech Republic. Journal of Comparative Economics, 27, 498-513. http://dx.doi.org/10.1006/jcec.1999.1598

Claessens, S., Djankov, S., \& Lang, L. H. P. (2000). The separation of ownership and control in East Asian corporations. Journal of Financial Economics, 58, 81-112. http://dx.doi.org/10.1016/S0304-405X(00)00067-2

Demsetz, H., \& Villalonga, B. (2001). Ownership structure and corporate performance. Journal of Corporate Finance, 209-233. http://dx.doi.org/10.1016/S0929-1199(01)00020-7

Gedajlovic, E., \& Shapiro, D. (1998). Management and ownership effects: evidence from five countries. Strategic Management Journal, 19(6), 533-553. http://dx.doi.org/10.1002/(SICI)1097-0266(199806)19:6<533::AID-SMJ957>3.0.CO;2-\#

Gursoy, G., \& Aydogan, K. (2002). Equity Ownership Structure, Risk Taking, and Performance. Emerging Markets, Finance \& Trade, 38(6), 6-25.

Hansmann, H. (2000). The Ownership of Enterprise. The Belknap Press of Harvard University Press. England, 11-12.

Kiuri, R. M. (2013). The effects of ownership structure on bank profitability in Kenya. European Journal of Management Sciences and Economics, 1(2), 116-127.

Kobeissi, N., \& Sun, X. (2010). Ownership Structure and Bank Performance: Evidence from the Middle East and North Africa Region, Comparative Economic Studies, Palgrave Macmillan, 52(3), 287-323.

Kosak, M., \& Cok, M. (2008). Ownership structure and profitability of the banking sector: The evidence from the SEE region. Journal of Economics and Business, 26, 93-122.

La Porta, R., Lopez-de-Silanes, F., \& Shleifer, A. (1999). Corporate ownership around the world. Journal of Finance, 54, 471-517. http://dx.doi.org/10.1111/0022-1082.00115

La Porta, R., López-de-Silanes, F., Shleifer, A., \& Vishny, R. (1998). Law and finance. Journal of Political Economy, 106, 1113-115. http://dx.doi.org/10.1086/250042 
La Porta, R., Lopez-de-Silanes, F., Shleifer, A., \& Vishny, R. (2000). Investor protection and corporate governance. Journal of Financial Economics, 58, 3-27. http://dx.doi.org/10.1016/S0304-405X(00)00065-9

Micco A., Panizza U., \& Yañez M. (2004). Bank ownership and performance, working paper, Inter-American development bank, Banco Interamericano de Desarrollo (BID) Research Department.

Mitton, T. (2002). A Cross-Firm Analysis of the Impact of Corporate Governance on the East Asian Financial Crisis. Journal of Financial Economics, 64, 215-24. http://dx.doi.org/10.1016/S0304-405X(02)00076-4

Morck, R., Daniel, W., \& Bernard, Y. (2005). Corporate governance, economic entrenchment and growth. Journal of Economic Literature, 43, 655-720. http://dx.doi.org/10.1257/002205105774431252

$\mathrm{Ng}$, C. Y. M. (2005). An Empirical Study on the Relationship between Ownership and Performance in a Family-Based Corporate Environment. Journal of Accounting, Auditing and Finance, 121-146

Nguyen Hong Son, \& Tran Thi Thanh Tu. (2012). Unknown issues of banking restructure in Vietnam nowadays. Autumn Economic Forum, co-hosted by Economic Committee of Parliament and UNDP, September, 2012.

Nguyen Hong Son, \& Tran Thi Thanh Tu. (2014, March). Vietnam banking system - results after 2 years of restructuring. Journal of Economic Research.

Nguyen Hong Son, Tran Thi Thanh Tu, \& Pham Bao Khanh. (2014, June). Testing the relationship between corporate governance and bank performance - an empirical test in Vietnam. Asian Social Science, 10(11).

Nguyen Hong Son, Tran Thi Thanh Tu, \& Tran Thi Hoang Yen. (2014, April). Bank restructuring - International perspectives and Vietnam practice. Accounting \& Finance Research Journal, 3(2).

Nguyen Hong Son. (2012). Bank restructuring: Theoretical issues, Asian experiences and implications for Vietnam. Journal of Economic Research, 7.

Nguyen Thi Minh Hue, \& Tran Thi Thanh Tu. (2012). Application of FSI in financial soundness assessment of Vietnam banking system. National Symposium, co-hosted by Economic Committee of Parliamentand National Economic University, March, 2012.

OECD. (2004). Principles of Corporate Governance.

Pedersen, T., \& Thomsen, S. (1999). Economic and Systemic Explanations of Insider ownership among Europe's Largest Companies. International Journal of the Economics of Business, 6(3), 367-381. http://dx.doi.org/10.1080/13571519984133

Pei Sai Fan. (2004). Is Board Diversity Important for Corporate Governance and Firm Value? Review of Literature \& Empirical Research.

Sun, Q., \& Tong, H. S. (2003) China share issue privatization: the extent of its success. Journal of Financial Economics, 70, 183-222. http://dx.doi.org/10.1016/S0304-405X(03)00145-4

Tran Thi Thanh Tu, Pham Bao Khanh, \& Phung Duc Quyen. (2014). Develop Corporate Governance Index for Vietnamese Bank. International Journal of Financial Research, 5(2).

Uwalomwa, U., \& Olamide, O. (2012). An Empirical Examination of the Relationship between Ownership Structure and the Performance of Firms in Nigeria. International Business Research, 208-215.

Vethanayagam, J., Yahya, S., \& Haron, H. (2006). Independent Non-Executive Directors, Managerial Ownership and Firm Performance in Malaysian Public Listed Companies. Proceeding Symposium on accountability, Governance and Performance. Griffith University, 2006.

Wen, W. (2010). Ownership structure and Banking Performance: New Evidence in China. Working paper.

Note

Note 1. See for more details: "Restructuring credit institutions system period 2011-2015". http://www.NHNN.gov.vn. 
Appendices: Regression models

Model 1. Testing the impact of ownership structure on ROA

\begin{tabular}{|c|c|c|c|c|c|c|}
\hline ource | & SS & $\mathrm{df}$ & MS & Number of obs & & 102 \\
\hline & & & & $\mathrm{F}(7$, & $=$ & 3.08 \\
\hline Model | & 11.6305724 & 7 & 1.66151034 & Prob $>$ F & $=$ & 0.0057 \\
\hline esidual & 50.65141 & 94 & .538844788 & R-squared & $=$ & 0.1867 \\
\hline & & & & Adj R-squared & $=$ & 0.1262 \\
\hline & 2017024 & 101 & 616653291 & Root MSE & $=$ & .73406 \\
\hline
\end{tabular}

\begin{tabular}{|c|c|c|c|c|c|c|}
\hline roa $\mid$ & Coef. & Std. Err. & $\mathrm{t}$ & $\mathrm{P}>|\mathrm{t}|$ & \multicolumn{2}{|c|}{ [95\% Conf. Interval] } \\
\hline cgi $\mid$ & .0034534 & .0073592 & 0.47 & 0.640 & -.0111584 & .0180653 \\
\hline $\mathrm{x} 1 \mathrm{oc}$ & .7112891 & .4069694 & 1.75 & 0.084 & -.0967582 & 1.519336 \\
\hline $\mathrm{x} 2 \mathrm{fo}$ & -1.286925 & .6409971 & -2.01 & 0.048 & -2.55964 & -.0142101 \\
\hline x3do & -.4014745 & .2055522 & -1.95 & 0.054 & -.8096032 & .0066542 \\
\hline $\mathrm{x} 4 \mathrm{so}$ & -.0740603 & .4218908 & -0.18 & 0.861 & -.9117343 & .7636138 \\
\hline x5po & 1.098114 & .4063929 & 2.70 & 0.008 & .2912111 & 1.905016 \\
\hline npls | & -7.622069 & 4.039752 & -1.89 & 0.062 & -15.64309 & .3989528 \\
\hline _cons $\mid$ & .8986673 & .3210702 & 2.80 & 0.006 & .261175 & 1.53616 \\
\hline
\end{tabular}

Model 2. Testing the impact of ownership structure on ROA, reducing CGI \& X4 variables

\begin{tabular}{|c|c|c|c|c|c|}
\hline Source | & SS & $\mathrm{df}$ & MS & Number of obs & 102 \\
\hline & + & & - & $\mathrm{F}(5$, & 4.35 \\
\hline Model | & 11.5068744 & 5 & 2.30137488 & Prob $>$ F & $=0.0013$ \\
\hline Residual | & \begin{tabular}{|l|l|} 
& 50.775108
\end{tabular} & 96 & .528907375 & R-squared & $=0.1848$ \\
\hline & & & ----- & Adj R-squared & $=0.1423$ \\
\hline Total | & 62.2819824 & 101 & .616653291 & Root MSE & $=.72726$ \\
\hline
\end{tabular}

\begin{tabular}{cccccccc} 
roa $\mid$ & Coef. & Std. Err. & $\mathrm{t}$ & $\mathrm{P}>\mathrm{t} \mid$ & \multicolumn{3}{l}{ [95\% Conf. Interval] } \\
\hline $\mathrm{-}$ x1oc $\mid$ & .7463618 & .295198 & 2.53 & 0.013 & .1603985 & 1.332325 \\
$\mathrm{x} 2 \mathrm{fo} \mid$ & -1.302049 & .6289176 & -2.07 & 0.041 & -2.550441 & -.0536579 \\
$\mathrm{x} 3 \mathrm{do} \mid$ & -.4047031 & .203404 & -1.99 & 0.049 & -.8084569 & -.0009493 \\
$\mathrm{x} 5 \mathrm{po} \mid$ & 1.169118 & .3671747 & 3.18 & 0.002 & .4402818 & 1.897954 \\
$\mathrm{npls} \mid$ & -7.737235 & 3.963797 & -1.95 & 0.054 & -15.60531 & .1308388 \\
cons $\mid$ & 1.022274 & .1835967 & 5.57 & 0.000 & .6578377 & 1.386711
\end{tabular}


Model 3. Testing the impact of onweship structure on ROA, reducing NPL variable

\begin{tabular}{|c|c|c|c|c|c|}
\hline Source | & SS & $\mathrm{df}$ & MS & Number of ob & 102 \\
\hline & & & 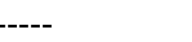 & $\mathrm{F}(6$, & 2.93 \\
\hline Model| & 9.71234507 & 6 & 1.61872418 & Prob $>$ F & $=0.0116$ \\
\hline Residual | & 52.5696373 & 95 & .553364603 & R-squared & $=0.1559$ \\
\hline & & & & Adj R-squared & $=0.1026$ \\
\hline otal | & 62.2819824 & 101 & .616653291 & Root MSE & .74388 \\
\hline
\end{tabular}

\begin{tabular}{|c|c|c|c|c|c|c|}
\hline roa $\mid$ & Coef. & Std. Err. & $\mathrm{t}$ & $\mathrm{P}>|\mathrm{t}|$ & \multicolumn{2}{|c|}{ [95\% Conf. Interval] } \\
\hline cgi $\mid$ & .0046128 & .0074316 & 0.62 & 0.536 & -.0101408 & .0193665 \\
\hline $\mathrm{x} 1 \mathrm{oc}$ & .6587176 & .4114484 & 1.60 & 0.113 & -.1581107 & 1.475546 \\
\hline $\mathrm{x} 2 \mathrm{fo}$ & -1.182575 & .6471535 & -1.83 & 0.071 & -2.467337 & .1021872 \\
\hline $\mathrm{x} 3 \mathrm{do}$ & -.4053626 & .2082927 & -1.95 & 0.055 & -.818876 & .0081507 \\
\hline $\mathrm{x} 4$ so & .0011591 & .4256241 & 0.00 & 0.998 & -.8438116 & .8461297 \\
\hline $\mathrm{x} 5 \mathrm{po}$ & 1.094688 & .4118278 & 2.66 & 0.009 & .2771061 & 1.912269 \\
\hline cons & .6571038 & .2983795 & 2.20 & 0.030 & .0647455 & 1.249462 \\
\hline
\end{tabular}

Model 4. Testing the impact of ownership structure on ROE

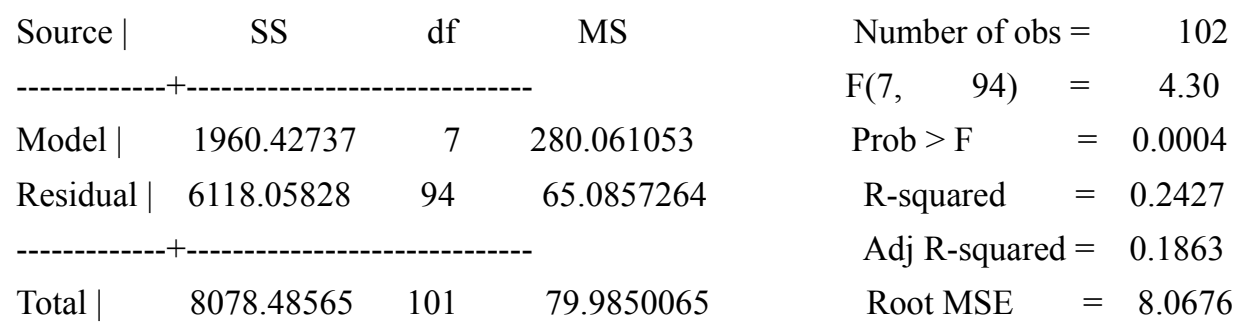

\begin{tabular}{|c|c|c|c|c|c|c|}
\hline roe & Coef. & Std. Err. & $\mathrm{t}$ & $\mathrm{P}>|\mathrm{t}|$ & \multicolumn{2}{|c|}{ [95\% Conf. Interval] } \\
\hline cgi $\mid$ & .2104748 & .08088 & 2.60 & 0.011 & .0498857 & .3710639 \\
\hline $\mathrm{x} 1 \mathrm{oc}$ & 4.076491 & 4.472731 & 0.91 & 0.364 & -4.804221 & 12.9572 \\
\hline $\mathrm{x} 2 \mathrm{fo}$ & -6.463595 & 7.044775 & -0.92 & 0.361 & -20.45116 & 7.52397 \\
\hline x3do & -3.221723 & 2.259088 & -1.43 & 0.157 & -7.707195 & 1.263749 \\
\hline $\mathrm{x} 4 \mathrm{so}$ & 2.921776 & 4.636723 & 0.63 & 0.530 & -6.284545 & 12.1281 \\
\hline x5po & 5.042173 & 4.466395 & 1.13 & 0.262 & -3.825959 & 13.91031 \\
\hline npls | & -98.30007 & 44.39824 & -2.21 & 0.029 & -186.4538 & -10.14633 \\
\hline cons $\mid$ & 3.195457 & 3.52867 & 0.91 & 0.367 & -3.810799 & 10.20171 \\
\hline
\end{tabular}


Model 5. Testing the impact of ownership structure on ROE, reducing the meaningless statistically variables

\begin{tabular}{|c|c|c|c|c|c|c|}
\hline Source | & SS & $\mathrm{df}$ & MS & Number of ob & $s=$ & 102 \\
\hline & & & & $\mathrm{F}(3$, & $=$ & 81.60 \\
\hline Model | & 15744.8585 & 3 & 5248.28618 & Prob $>$ F & $=$ & 0.0000 \\
\hline esidual & 6367.53789 & 99 & 64.3185645 & R-squared & $=$ & 0.7120 \\
\hline & & & & Adj R-squa & & 0.7033 \\
\hline tal & 112.3964 & 102 & 216.7882 & Root MSE & $=$ & 8.0199 \\
\hline
\end{tabular}

\begin{tabular}{rcccccc} 
roe $\mid$ & Coef. & Std. Err. & $\mathrm{t}$ & $\mathrm{P}>|\mathrm{t}|$ & \multicolumn{3}{c}{$[95 \%$ Conf. Interval] } \\
\hline $\mathrm{cgi} \mid$ & .3179871 & .0303246 & 10.49 & 0.000 & .2578165 & .3781578 \\
$\mathrm{x} 3 \mathrm{do} \mid$ & -1.854089 & 1.820458 & -1.02 & 0.311 & -5.466272 & 1.758093 \\
npls $\mid$ & -87.09275 & 39.60774 & -2.20 & 0.030 & -165.6831 & -8.502394
\end{tabular}

Model 6. Testing the impact of ownership structure on ROE, reducing NPL variable

\begin{tabular}{|c|c|c|c|c|c|c|}
\hline Source | & SS & df & MS & Number of obs & & 102 \\
\hline & & & & $\mathrm{F}(6$, & $=$ & 4.04 \\
\hline Model | & 1641.37504 & 6 & 273.562507 & Prob $>$ F & $=$ & 0.0012 \\
\hline Residual | & 6437.11061 & 95 & 67.759059 & R-squared & $=$ & 0.2032 \\
\hline & & & & Adj R-squared & $=$ & 0.1529 \\
\hline Total | & 8078.48565 & 101 & 79.9850065 & Root MSE & $=$ & 8.2316 \\
\hline
\end{tabular}

\begin{tabular}{|c|c|c|c|c|c|c|}
\hline roe $\mid$ & Coef. & Std. Err. & $\mathrm{t}$ & $\mathrm{P}>|\mathrm{t}|$ & \multicolumn{2}{|c|}{ [95\% Conf. Interval] } \\
\hline cgi $\mid$ & .2254274 & .0822361 & 2.74 & 0.007 & .0621681 & .3886868 \\
\hline $\mathrm{x} 1 \mathrm{oc}$ & 3.398488 & 4.552955 & 0.75 & 0.457 & -5.64027 & 12.43725 \\
\hline $\mathrm{x} 2 \mathrm{fo}$ & -5.117818 & 7.161192 & -0.71 & 0.477 & -19.33458 & 9.098945 \\
\hline x3do & -3.271868 & 2.3049 & -1.42 & 0.159 & -7.847673 & 1.303938 \\
\hline x4so & 3.891862 & 4.709819 & 0.83 & 0.411 & -5.458311 & 13.24203 \\
\hline x5po & 4.997987 & 4.557153 & 1.10 & 0.276 & -4.049105 & 14.04508 \\
\hline _cons $\mid$ & .0800681 & 3.301772 & 0.02 & 0.981 & -6.474777 & 6.634913 \\
\hline
\end{tabular}

